and the labour analysis schedule and the inclusion of a diagram showing the organization of a small works. Copies can be obtained from the British Institute of Management, 8 Hill Street, London, W.1, price $2 s .6 d$., including postage. The Institute is also preparing a similar publication for more general application.

\section{Royal Society Lectures for 1951}

THE subject, speaker and date of the Royal Society Lectures for 1951 have been announced as follows : Croonian Lecture, "Lethal Synthesis", by Prof. R. A. Peters, Whitley professor of biochemistry, Oxford, on June 7; Bakerian Lecture, "Reactions in Monolayers", by Prof. E. K. Rideal, professor of chemistry, King's College, London, on June 21; Leeuwenhoek Lecture, "The Place of Viruses in Nature", by Dr. C. H. Andrewes, National Institute for Medical Research, Mill Hill, on December 13.

Association of Applied Biologists: Officers for 1951

THE following are the officers for 1951 of the Association of Applied Biologists : President, R. W. Marsh; Vice-Presidents, Dr. J. W. Evans and Dr. H. C. Gough ; Honorary Treasurer, Dr. H. F. Barnes ; Honorary General Secretary, Dr. R. K. S. Wood (Imperial College, London, S.W.7) ; Honorary Programme Secretary, Dr. L. Broadbent (Rothamsted Experimental Station, Harpenden, Herts) ; Honorary Editor of the Annals of A pplied Biology, R. W. Marsh ; Honorary Assistant Editor, Dr. I. Thomas.

\section{University of . London}

THE following announcements have recently been made by the University of London. D. R. Bates and Dr. R. A. Buckingham have been appointed to University readerships in physics, tenable at University College. The title of reader in aeronautical engineering in the University has been conferred on Dr. L. G. Whitehead, in respect of the post held by him at Queen Mary College. The degree of D.Sc. has been conferred on E. Lewis-Faning and E. A. R. Braude.

\section{Evaluation of Chemotherapeutic Substances}

The Biological Methods Group of the Society of Public Analysts and Other Analytical Chemists is arranging an open symposium on the evaluation of chemotherapeutic substances, to be held in London during October 26-27, with Dr. G. W. M. Findlay in the chair. Papers will be presented dealing with the assay of anti-bacterial, anti-protozoal and similar substances by both in vivo and in vitro methods. Intending contributors should write to the honorary secretary, S. A. Price, at Walton Oaks, Dorking Road, Tadworth, Surrey.

\section{Announcements}

The Lord Pressident of the Council has appointed Dr. D. D. Pratt, acting director of the Chemical Research Laboratory, Teddington, to be director of the Laboratory. Sir Robert Robinson has accepted the invitation of the Lord President to act as an honorary consultant to the Laboratory on research in pure organic chemistry.

The Aluminium Development Association is offering a research scholarship, of value $£ 400$ a year and tenable for two years, for the encouragement of research into the application of light alloys to ship construction. Further particulars of entry, which closes on June 30, can be obtained from the Secretary, Institution of Naval Architects, 10 Upper Belgrave Street, London, S.W.1.

The Ministry of Agriculture and Fisheries and the Department of Agriculture for Scotland are offering, for the academic year beginning October 1 or earlier, a limited number of postgraduate scholarships in agricultural economies, husbandry, statistics and agricultural and dairy engineering. Further particulars and application forms (to be completed by May 1) can be obtained from the Secretary, Ministry of Agriculture and Fisheries (Research Branch), 1-4 Cambridge Terrace, Regent's Park, London, N.W.1, or the Secretary, Department of Agriculture for Scotland, St. Andrew's House, Edinburgh, 1.

IN order to induce younger scientific workers to take an interest in the work of the British Association for the Advancement of Science and to raise the literary standard of scientific writing, Imperial Chemical Industries, Ltd., publisher of Endeavour, is again offering four prizes totalling 90 guineas to be awarded for an essay, not exceeding four thousand words, on a given scientific subject. Competitors must be less than twenty-five years old and must send in their essays before June 1. Further details of these prizes, which are to be known as Endeavour prizes, can be obtained from the Assistant Secretary, British Association for the Advancement of Science, Burlington House, Piccadilly, London, W.1.

The summer meetings of the Royal Astronomical Society will be held at the University College of the South West, Exeter, during July 24-26. In addition to the usual proceedings, a popular lecture, a geophysical discussion and an excursion to the Norman Lockyer Observatory at Sidmouth will be arranged. Further details can be obtained from the assistant secretary of the Royal Astronomical Society, Burlington House, London, W.1.

THE ninety-sixth annual oxhibition of the Royal Photographic Society will be held at 16 Princes Gate, London, S.W.7, during September 14-October 14, and afterwards in Scotland. All aspects of photography (including narrow-gauge kinematography) will be exhibited. The closing date for entries, from members and non-members alike, is July 31 , and details can be obtained from the secretary at the above address.

THE Textile Institute will hold its annual general meeting at the Midland Hotel, Manchester, on April 18. The meeting will be followed by the Mather Lecture, which this year is to be given by Dr. J. C. Withers, a vice-president of the Textile Institute and former head of the Library and Information Service of the British Cotton Industry Research Association, who will speak about information on textiles. The Mather Lecture, which is an annual event, was inaugurated in 1919 to perpetuate the memory of the late Sir William Mather, president of the Institute during 1915-17 and promoter of the Institute's Foundation Fund in 1919.

ErRatum. In the communication "Influence of Folic Acid on Xanthine Oxidation in vitro" by Miss P. Fatterpaker and Dr. A. Sreenivasan in Nature of January 27 , p. 149 , par. 2, line 13 , for " $1 \cdot 5 \mathrm{gm}$." read " $1.5 \mu \mathrm{gm} . "$. 